\title{
Adoption of Vermicomposting Technology for Livelihood Improvement of Farmers in Chittorgarh District of Rajasthan, India
}

\author{
Ratan Lal Solanki* and Deepa Indoria \\ KVK, Chittorgarh, Maharana Pratap University of Agriculture and Technology, \\ Udaipur (Rajasthan), India \\ *Corresponding author
}

\begin{tabular}{l} 
Key w o r d s \\
Adoption, \\
Vermicomposting \\
Technology, \\
Farmer, FLD, KVK, \\
Popularization \\
\hline Article Info \\
\hline $\begin{array}{l}\text { Accepted: } \\
17 \text { April } 2020 \\
\text { Available Online: } \\
10 \text { May } 2020\end{array}$ \\
\hline \hline
\end{tabular}

\section{A B S T R A C T}

The awareness for vermicompost production for soil health as well as for entrepreneurship development was created among the rural population of Chittorgarh district of Rajasthan by Krishi Vigyan Kendra, Chittorgarh through Front Line Demonstration programmes. The FLD programmes were conducted during year 2015 to 2017 and the study was conducted during year 2018-19. The study was conducted on the beneficiaries of FLD programmes and total 100 farmers were selected randomly. The research design followed in the study was survey research method and the data collected by pretested well structure interview schedule. It is clear from the results that female farmers were more interested to adopt vermicompost (71.79\%) as compared to male farmers $(55.7 \%)$. The independent variables like gender, age, education, caste, income and land holding of farmers were the important variables for adoption of vermicompost technology. The study indicates that KVK, Chittorgarh was able to motivate the middle aged and middle school pass farmers to adopt the technology with the highest benefit-cost ratio (3.50). Therefore, there is need to popularize vermicompost technology among young farmers and SC \& ST community for greater upliftment of farming community.

\section{Introduction}

Vermicompost is highly nutritive and a powerful plant growth promoter and protector and is scientifically proving to be a miracle plant growth promoter. It is rich in NPK, micronutrients, beneficial soil microbes and also contains plant growth hormones and enzymes secreted by earthworms. Vermicompost retains nutrients for long time and also protect crops from pests and diseases. It has high moisture holding capacity and hence also reduces the use of water for irrigation by $40-50 \%$. Vermicompost rich in humus (secreted by earthworms) provide the ability to glue clay, silt and sand particles together enhancing the texture and structure of soil and preventing soil erosion. Vermicomposting is a modified and specialized method of composting where 
earthworms are used to eat and digest farm waste and turn into high quality compost in two months or less (Patel et al., 2015). The fine granular peat like end product, vermicompost that is produced is reported to contain elevated levels of nitrogen, phosphorus and potassium (NPK) in available form, micronutrients, microflora and enzymes (Edward, 2004; Ansari, 2011) as compared to the traditional compost. Secretions of earthworm that are in vermicompost serve as plant growth stimulating factor (Galli et al., 1990). Because of this, the vermicompost when applied or supplemented in the soil, it improves crop growth and yield (Zaller, 2007; Joyakumar et al., 2011). In addition, vermicompost produced by the joint action of earthworms and microbes, contains nutrients in available form with increased microbial activities (Aira et al., 2007). Vermicompost rich in humus provide the ability to glue clay, silt and sand particles together enhancing the texture and structure of soil and preventing soil erosion (Sreedevi and Hanchinal, 2017). The vermiwash can also be used as spray on crops. Various economic uses can be obtained from organic waste through Vermicomposting. As the cost of production is also very less, farmers can easily produce at village levels. The prime market for vermicompost is in agriculture and horticulture. Vermicompost is an eco-friendly natural fertilizer prepared from biodegradable organic wastes and is free from chemical inputs. It promotes better root growth and nutrient absorption and it improves nutrient status of soil both macro and micro-nutrients and also the physical, chemical and biological properties of the soil and it improves soil aeration, texture and tilth thereby reducing soil compaction. Taking in to consideration the need for higher production of vermicompost and lack of empirical studies as far as knowledge, adoption and constraints from the farmers' point of view in Chittorgarh, Rajasthan area, the present study was undertaken with an objective to know the knowledge and adoption of farmers about vermicomposting technology. To popularise the vermicompost process among the small and marginal farmers of Chittorgarh district; KVK, Chittorgarh created awareness among the farmers through front line demonstration and training to transfer the vermicompost production technology with low cost structures. The FLD programmes were conducted during year 2015 to 2017 and the study was conducted during the year 2018-19. The purpose of the study was to identify the adoption percentage of beneficiaries and its distribution among the different independent variable selected for the study.

\section{Materials and Methods}

The study on adoption percentage was conducted on the respondent of Chittorgarh district, who practiced FLD programme imparted by Krishi Vigyan Kendra, Chittorgarh from 2015-16 to 2017-18. The research design followed in the study was survey research method and the data collected by pretested well structure interview schedule. Demonstration and low cost production system techniques were used to motivate the farmers. Front line demonstrations (FLD) were conducted by KVK, Chittorgarh in a systematic way on farmer's field to show the worth of Vermicomposting technology and to convince the farmers to adopt the technology for better soil health as well as better livelihood of the farmers. Under vermicompost FLD programme, Farmers are taught about different Vermi beds like low cost heap method/simple bed, silpaulin plastic bag bed and concrete paka Vermi beds and along with earthworms / Vermiculture were distributed to farmers as seed. A total of 100 beneficiaries were selected randomly for the study, thus constituting the total sample size of 100 respondents. The dependent variable of this 
study was adoption and independent variables were gender, age, education, caste, income and land holding of farmers. The data were collected using pre-tested structured interview schedule personally. Adoption percentage of each category calculated as:

\section{Adoption percentage $=$}

Number of respondent adopted the technology X 100 Number of respondent participated

\section{Results and Discussion}

It was shown from the investigation that a majority of the respondent participated in vermicompost front line demonstration were male farmers $(61 \%)$ followed by female farmer (39\%) in (Table 1). But after the demonstration, it is found that majority percentage of respondent adopted vermicompost were female (71.79 \%) followed by male farmer $(55.7 \%)$. The results showed that female beneficiaries of Chittorgarh district were more motivated for Vermicomposting than the male farmers. This result contradicts the results of Das et al., (2016) where adoption percentage was found maximum with male farmers. It was also found from the survey that majority of farmers from the age group 35 yrs to 50 years participated in the FLD programmes (52\%) and adopted the technology (75\%) followed by the age group 25 years 35 years (68\%). These results showed that the farmers group belonging to the age group 35 years to 50 years were more concerned about the extra earning. Increased financial burden may be the reason for adoption of vermicompost of this age group. From the study, it was found that beneficiaries under the category middle school pass adopted the technology highest $(68.75 \%)$ followed by high school category $(56.76 \%)$ compared to other education level whereas the maximum participation was from the high school category (37\%).
The myth about the education level may be the reason for such adoption percentage. Highest participation was observed among the farmers of OBC category (51\%) and adopted as well $(74.51 \%)$ followed by the farmers of SC category (57.14 \%). As Chittorgarh district adopted village is dominated by $\mathrm{OBC}$ population, so maximum adoption was observed among this category. With the independent variable income, maximum adoption was found among the farmers of income group Rs 60,000 to Rs. $1,00,000$ $(72.72 \%)$, followed by the income group Rs.40,001 to Rs. 60,000 (66.66\%) where maximum participation was observed among the farmers of income group Rs 60,001 to Rs. $1,00,000$ (33\%) followed by income group Rs. $1,00,001$ to $2,00,000$ (30\%). Farmers group having land holding between $0.5 \mathrm{~h}$ to 1.0 ha had highest participation percentage (49\%) and showed the highest adoption percentage $(75.51 \%)$ followed by the group of farmers having land holding $<0.5$ ha $(66.66 \%)$ and land holding $>1$ ha $(41.66 \%)$. It was found from the investigation (Table 2) that overall percentage of adoption of vermicompost production was $62 \%$ out of 100 respondents, 62 nos of farmers adopted the technology for upliftment of their socio economic condition. These findings are supported by various workers (Das et al., 2016, Aski and Hirevenkanagoudar, 2010). Describes (Table 3) the economic benefit of low cost vermicompost units in the form of benefit cost ratio. The benefit cost ratio (3.50) was recorded highest in concrete paka bed followed by production in plastic bag bed (3.36) than kaccha bed/ heap method units (2.35). Vermicompost produced in paka bed /concrete bed in first year could not give enough benefit as the costs of construction of paka bed /concrete bed were too high. From 2nd year onwards benefit cost ratio was recorded as 3.50 (Fig. 1). 
Table.1 Adoption percentage of respondent with different independent variable

\begin{tabular}{|c|c|c|c|c|c|}
\hline S.No. & Variable & $\begin{array}{l}\text { No of } \\
\text { participants }\end{array}$ & $\begin{array}{l}\text { No of } \\
\text { adopted }\end{array}$ & $\begin{array}{l}\text { Participant } \\
\%\end{array}$ & Adoption \% \\
\hline $\mathbf{A}$ & \multicolumn{5}{|l|}{ Gender } \\
\hline 1. & Male & 61 & 34 & 61.0 & 55.70 \\
\hline 2. & Female & 39 & 28 & 39.0 & 71.79 \\
\hline B & \multicolumn{5}{|l|}{ Age } \\
\hline 1. & 18 yrs to $<25$ yrs & 23 & 10 & 23.0 & 43.47 \\
\hline 2. & $25 \mathrm{yrs}$ to $<35 \mathrm{yrs}$ & 25 & 17 & 25.0 & 68.00 \\
\hline 3. & $35 \mathrm{yrs}$ to $<50 \mathrm{yrs}$ & 52 & 39 & 52.0 & 75.00 \\
\hline $\mathbf{C}$ & \multicolumn{5}{|l|}{ Educational Levels } \\
\hline 1. & Illiterate & 04 & 01 & 04.0 & 25.00 \\
\hline 2. & Can read only - - & 06 & 02 & 06.0 & 33.33 \\
\hline 3. & Can read and write & 08 & 04 & 08.0 & 50.00 \\
\hline 4. & Primary school & 13 & 07 & 13.0 & 53.84 \\
\hline 5. & Middle School & 32 & 22 & 32.0 & 68.75 \\
\hline 6. & High School & 37 & 21 & 37.0 & 56.76 \\
\hline D. & \multicolumn{5}{|l|}{ Caste } \\
\hline 1. & $\mathrm{OBC}$ & 51 & 38 & 51.0 & 74.51 \\
\hline 2. & $\mathrm{SC}$ & 28 & 16 & 28.0 & 57.14 \\
\hline 3. & ST & 21 & 11 & 21.0 & 52.38 \\
\hline $\mathbf{E}$ & Annual income level & & & & \\
\hline 1. & Less than Rs 40,000 & 06 & 02 & 06.0 & 33.33 \\
\hline 2. & Rs. 40,001 to 60,000 & 15 & 10 & 15.0 & 66.66 \\
\hline 3. & Rs. 60,001 to $1,00,00$ & 33 & 24 & 33.0 & 72.72 \\
\hline 4. & $1,00,001$ to $2,00,000$ & 30 & 19 & 30.0 & 63.33 \\
\hline 5. & $2,00,001$ to $4,00,000$ & 10 & 04 & 10.0 & 40.00 \\
\hline 6. & $>4,00,000$ & 06 & 03 & 06.0 & 50.00 \\
\hline F. & Land holding & & & & \\
\hline 1. & $<0.5$ ha & 27 & 18 & 27.0 & 66.66 \\
\hline 2. & 0.5 ha to 1.0 ha & 49 & 37 & 49.0 & 75.51 \\
\hline 3. & $>1.0 \mathrm{ha}$ & 24 & 10 & 24.0 & 41.66 \\
\hline
\end{tabular}

Table.2 Adoption percentage of vermicompost production

\begin{tabular}{|l|l|}
\hline S.N. & $\begin{array}{l}\text { Total number. of } \\
\text { respondent adopted } \\
\text { Vermicomposting }\end{array}$ \\
\hline 1. & 62 \\
\hline
\end{tabular}

\begin{tabular}{|l|l|}
\hline $\begin{array}{l}\text { Total number of } \\
\text { respondent } \\
\text { participated }\end{array}$ & $\begin{array}{l}\text { Adopt } \\
\text { perce }\end{array}$ \\
\hline 100 & 62.00 \\
\hline
\end{tabular}

Total number of participated 
Table.3 Economics of low cost kaccha, plastic bed and concrete paka beds of Vermicomposting

\begin{tabular}{|l|c|c|c|c|c|}
\hline $\begin{array}{l}\text { Type of } \\
\text { Vermicompost Beds }\end{array}$ & $\begin{array}{c}\text { Size of beds in } \\
\text { feets }\end{array}$ & $\begin{array}{c}\text { Cost of } \\
\text { Production Gross } \\
\text { (Rs) }\end{array}$ & $\begin{array}{c}\text { Gross } \\
\text { return } \\
\text { (Rs) }\end{array}$ & $\begin{array}{c}\text { Net } \\
\text { return } \\
\text { (Rs) }\end{array}$ & $\begin{array}{c}\text { B:C } \\
\text { ratio }\end{array}$ \\
\hline $\begin{array}{l}\text { Kaccha bed/ Heap } \\
\text { method }\end{array}$ & $15 \times 3 \times 1.5$ & 1700 & 4000 & 3700 & 2.35 \\
\hline Plastic bed & $12 \times 4 \times 2$ & 5000 & 16800 & 11800 & 3.36 \\
\hline $\begin{array}{l}\text { Paka bed/ concrete } \\
\text { thanks }\end{array}$ & $15 \times 3 \times 1.5$ & 18000 & 19000 & 4100 & $*$ \\
\hline
\end{tabular}

*First Year

**Second year

Fig.1 Photograph of different vermicompost beds

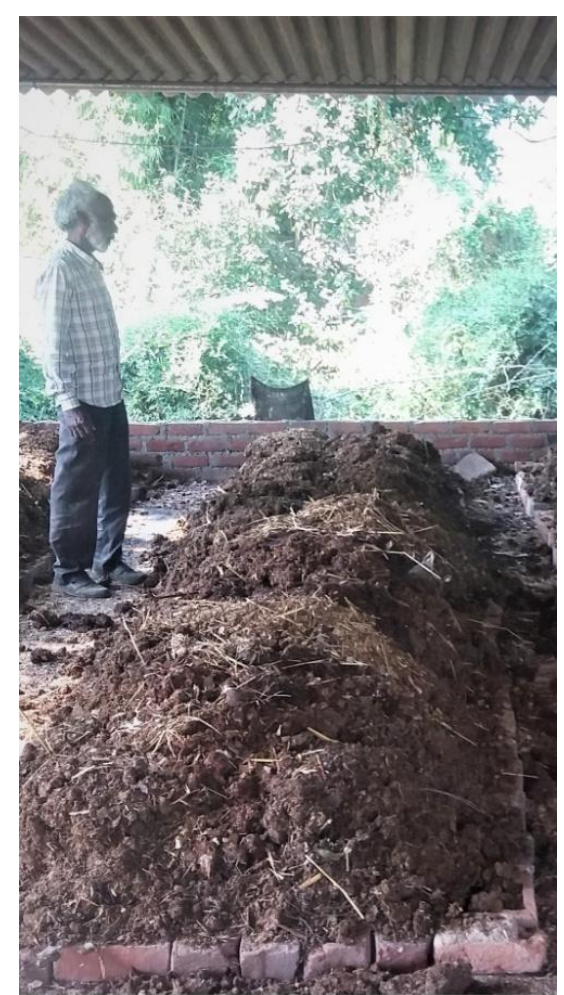

Heap Method V.C. Bed

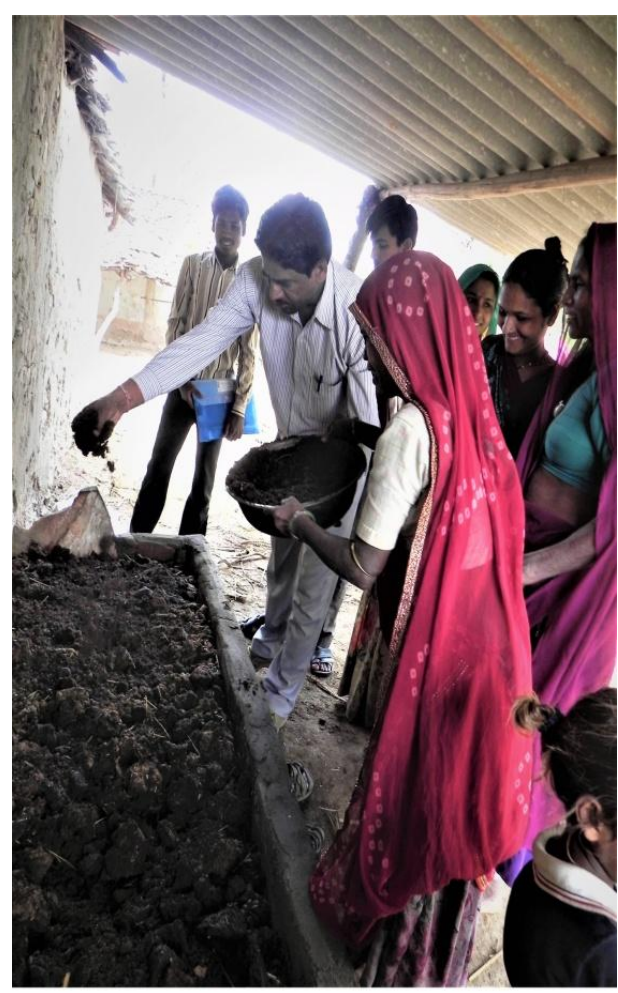

Pakka/Concrete Vermi Bed
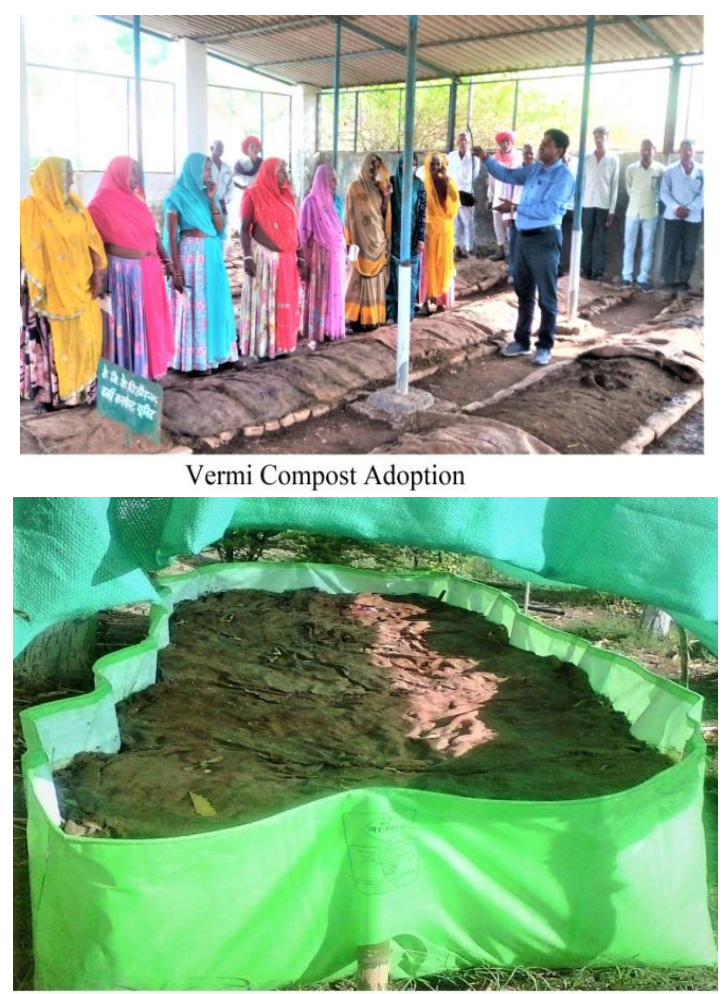

Plastic Vermi Bed
In conclusion, the present study indicated that the farmers were medium in knowledge and favourable in attitude about vermicompost technology. Important constraints in adoption of vermicompost faced by farmers were nonavailability of worms in nearby market, lack of knowledge and guidance about preparation of vermicompost technology. It could be concluded that female farmers were more interested to adopt vermicompost as compared to male farmers. The independent variables like gender, age, education, caste, income and land holding of farmers were the important variables for adoption of vermicomposting technology. The study indicates that KVK, Chittorgarh was able to 
motivate the middle aged and middle school pass farmers. Therefore, there is need to popularize vermicompost technology among young farmers and SC and ST community for greater up liftment of farming community. Hence, extension efforts should be directed to overcome these constraints in order to increase the adoption level by the farmers.

\section{References}

Aira, M., Monroy, F., and Dom'inguez, J. (2007). Earthworms strongly modify microbial biomass and activity triggering enzymatic activities during Vermicomposting independently of the application rates of pig slurry. Science of the Total Environment. 385(1-3): 252-261.

Ansari, A. A. (2011). Worm powered environmental biotechnology in organic waste management. International Journal of Soil Science. 6 (1): 25-30.

Aski, S. G., Hirevenkanagoudar. (2010). Extent of adoption of vermicompost practices by the KVK trained farmers. Asian Sciences 5(2): 85-88.

Das, G., Sarkar, S., Das, S. K., and Biswas, S. (2016). Adoption of vermicompost production with respect some socioeconomic variable. International Journal of Agricultural Sciences. 8(4): 14781480.

Edwards, C. A., and Arancon, N.Q. (2004).
The use of earthworms in the breakdown of organic wastes to produce vermicompost and animal feed protein. In: Edwards C.A. (Ed), Earthworm Ecology, second ed. CRC Press, Boca Raton, Fla, USA, 345-38.

Galli, E., Tomati, V., Grappelli, A. and de Lene, G. (1990). Effect of earthworm cast on protein synthesis in Agaricus bisporus. Biol. Fert. Soil. 9: 1-2.

Jayakumar, M., Sivakami, T., Ambika, D., and Karmegam, N. (2011). Effect of turkey litter (Meleagris gallopavo L.) Vermicompost on growth and yield characteristics of paddy, Oryza sativa (ADT-37). African Journal of Biotechnology. 10(68): 15295-15304.

Patel, R. N., Prajapati, M. R., and Patel, V. T. (2015). Adoption behaviour of Tribal farmers for vermicompost technology. Gujral Journal of Extension Education. 26(1): 65-66.

Shridevi, A., Sankaratti, and Hanchilal, S. N. (2017). Adoption of Vermicomposting technology by farmers of Gulbarga district in Karnataka. Agriculture Update.12 (4): 639-642.

Zaller, J. G. (2007). Vermicompost as a substitute for peat in potting media: effects on germination, biomass allocation, yields and fruit quality of three tomato varieties. Scientia Horticulture. 112(2): 191-199.

\section{How to cite this article:}

Ratan Lal Solanki and Deepa Indoria. 2020. Adoption of Vermicomposting Technology for Livelihood Improvement of Farmers in Chittorgarh District of Rajasthan, India. Int.J.Curr.Microbiol.App.Sci. 9(05): 2276-2281. doi: https://doi.org/10.20546/ijcmas.2020.905.259 